\title{
人體重心の新測定法（豫報）
}

寺田和夫

緒言

人の起居動作はすべて重力の影響下にあり、人體の形態、機能は密接に重力と關係してい る。人體は重力の力場內にあるから、そのあらゆる部分が重力によつて地球の中心に向かつ て引かれているが、この力は何れも平行で同じ向をとみなせるので、體の各部分飞働く重力 を、西る一點に合成することができる。ての點を重心或は質量中心と呼んでいる。重心は力 學的には勿論、生物學的にも重要な概念であつて、人體の靜止、運動、關節に及济す壓力等 を研究するとき、必示登場する問題であるにも拘らす、具體的に重心位置を求めようとする 試みは未だ十分に成功したとい.5ととはできない。

ての論文の方法が選ばれる迄の人體重心の研究史を一瞥すれば次の如くである。

人をシーソーのような中央の支點で釣合の取れる板の上に寝かせて、平衡の位置を求めれ ば、仰臥位の重心は、支點の鉛直上方にあるととは明らかである。ALFONSo BoRRELLI (1677) はての方法によつて人體の重心を測定した。

唯、この方法では人を板の上で動かしてて重心を探すので甚だ不便である。そこで上の梖杆 の支點を二つにし、その一つを固定し、他を科の上に置くならば、體重と重心の高さによつ て科の目盛の讀みが違つてくるであろら。今世紀初頭 Du-Bors-REYMOND によつて探用さ れたのが上の方法で、SCHEIDT の廣範圍な研究に刺㦸されて各方面で用いられるよらにな つた。身長に對する重心高の百分率による Chamae-, Ortho-, Hypsisorrhope の分類は SCHEIDT の定めたものであるが、彼はその他に、重心高の標準偏差が大きいとと、身長、 脚長との相關が小さいとと、スポーツ體型と關係があるとと、等の重要な報告を行つている。 日本でも古くは秋田氏がこの方法によつて、多數の個體を調べて日本人の重心高が低く、日 本人兒童では大部分 SCHEIDT の分類の Chamaeisorrhope にはいつてしまうとと、重心位 置は成長すると共に上に上るとと等を注意した。

以上の各研究は人體の重心が體のある固定した一點に實在するが如く扱つているが、實は 重心とは體の各部位に働く重力の合成された點であるから、姿势によつて變化するものであ る。從つてある姿勢沉於ける重心位置を求めるととはできても、一般的に人體の重心がぞて にあるかを云ふするととは不可能で西り、上述の研究によつて知られたのは、仰臥位に於け る綜合重心の位置が、足から頭の方向に於けるどの部分の鉛直斷面に來るかといらととに過 ぎない。そとで O. F ISCHER は頭、四肢、胴體等の各部分は、切り離して考えればそれぞ れ重心位置の㹬ら゙決つた剛體とみなせるととから、死體で切斷して求めた各部分の質量と重 心から體全體の綜合重心を計算によつて求めるととを思いついた。てれが彼の膨大な人體力 學の研究に用いられたが、確に步行の際の移りゆく點としての綜合重心を求めるためには有 意義な方法であり、從來の高さのみ、それも蔣を場合の高さとい5求め方に比して、とれを 


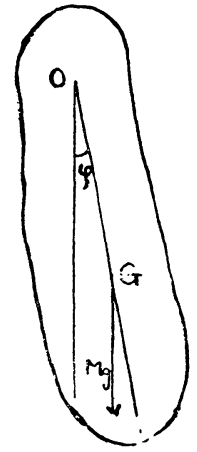

第 1 圖

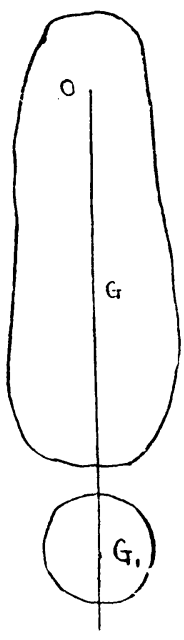

第; 2 圖

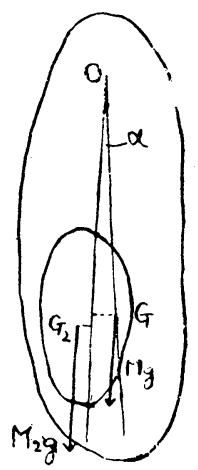

第 3 圖

三次元空間に於て動く點として捉 えたととは重心研究に一時期を劃 したものといえよう。

然しての方法の缺陷は、死體で 得られた體の各部分の質量、重心 を生體にそのま 適用するととに 㐫る。四肢の質量は、その長さよ りもむしろ骨の太さ等の、生體で は測定しえをい量に關係するとと が知られているから、死體てよく 似を proportion を持つ生體を得 るととができても、相互の質量分 布を直ちと等しいものとして扱 ことはできない。またその相違を

補正するてともできず、從つて綜合されを重心がどの程度誤差を持つているかを量的て決定 することもできないてとになる。かくして任意の姿勢に於ける綜合重心の位置決定の問題は 他のより直接的な方法に俟をねばならない。1920年代から BASLER は人體の重心の性質を 調べ、直立している時も、絕えず重心は前後左右に動き、精密に觀察すれば心藏の鼓動に件 ら週期的變化まで見られるととを報じた。その后、重心高の決定のためにぶらんとを用いて、 人をてれに乘せを後、一定の力を加えて生ボるフレの角から計算した。郎ち頑丈なぶらんと の下方に取りつけた棒に紐を結び、滑車を介して紐の他端に錘をぶらさげ、その銛によつて 生がるぶらんこのフレの角を精密に讀むのである。人が重く、且つ重心が低い程フレの角住 小さいであろ5。BASLER はこの方法によつて種くの姿勢に於ける重心高の决定に一應成功 した。

大體以上の經過を辿つて重心の決定法は進步してて來たけれを゙も、末だ簡單で精密さを失わ ない、然もその精密の程度を豫め决定できる方法は案出されていない。筆者は勞衝科學研究 所の奥山氏が、人體を乘せをぶらんこを一つの物理的振子として週期を決定することから重 心を計算する方法を發表されをのに暗示を得て、ある程度上の要求を滿をす政究方法を考案 した。

もとより、如何をる方法と雖も一長一短をもつととは言らまでもない。重心高の、二つの 集團に於ける相違を調べる上に REYMOND の仰臥位に於ける測定法は一つの規準を與える 便宜があり、姿勢の僢間的な動きを求めるには他に更に銳敏な方法も得られよら。我々の方 法は、他の人類學的計測と容易に比較され、然も廣範圍な研究に應用でき、特沉かっる測定 に必然的に生ずる誤差を量的に扱えるてとを目的としたものである。

方法

本論文の方法は、人體重心高の測定のためと、ぶらんと、郎ら一種の合成振子を用いてそ の週期を測定し、重心を計算によつて求めるものである。 
原理：一一水平な直線を伵轉軸として運動する岡體を複振子又は物理的振子とい5。今第 1 圖は剛體の重心 $\mathrm{G}$ を過ぎり廻轉軸 $\mathrm{O}$ 飞垂直な本面で切つた斷面を示すものとする。岡 體の質量を $\mathrm{M}, \mathrm{OG}$ が鉛直となす角を $\varphi, \mathrm{OG}=h$ とすれば $\varphi$ の增す方向と $\mathrm{O}$ 亿關する重 力の慣性能率 I とは逆に向いているから、次の運動方程式が成立つ。

$$
\mathrm{I} \frac{d^{2} \varphi}{d t^{2}}=-\mathrm{M} g h \sin \varphi
$$

こょで $\sin \varphi$ を とみなせる範圍ではこの剛體は單振動をなして週期 $\mathrm{T}$ は次の如くで ある。

$$
\mathrm{T}=2 \pi \sqrt{\frac{\mathrm{I}}{\mathrm{M} g h}}
$$

依つて週期 $T$ を測定するととによつて、hを知るととができるが、そのためには慣性能 率 I をも知らねばならない。だが人體の慣性能率は重心と同じく求め難いものである。そ こで第 2 圖の如く質量 $M_{1}$ 、慣性能率 $I_{1}$ の知られた物體を、この㓮體に附加する。このとき

$$
\mathrm{T}^{\prime}=2 \pi \sqrt{\frac{\mathrm{I}^{\prime}}{\mathrm{M}^{\prime} g h^{\prime}}}
$$

こなに附加した剛體の重心 $\mathrm{G}$ と迴轉軸 $\mathrm{O}$ との距離を $a$ とすれば、右邊は書き直されて

$$
\mathrm{T}^{\prime}=2 \pi \sqrt{\frac{\mathrm{I}+\mathrm{I}_{1}+a^{2} \mathrm{M}_{1}}{\left(h \mathrm{M}+a \mathrm{M}_{1}\right) g}}
$$

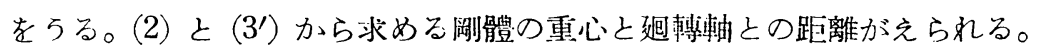

$$
h=\frac{4 \pi^{2} / g\left(a^{2} \mathrm{M}_{1}+\mathrm{I}_{1}\right)-a \mathrm{M}_{1} \mathrm{~T}^{\prime 2}}{\mathrm{M}\left(\mathrm{T}^{\prime 2}-\mathrm{T}^{2}\right)(4)}
$$

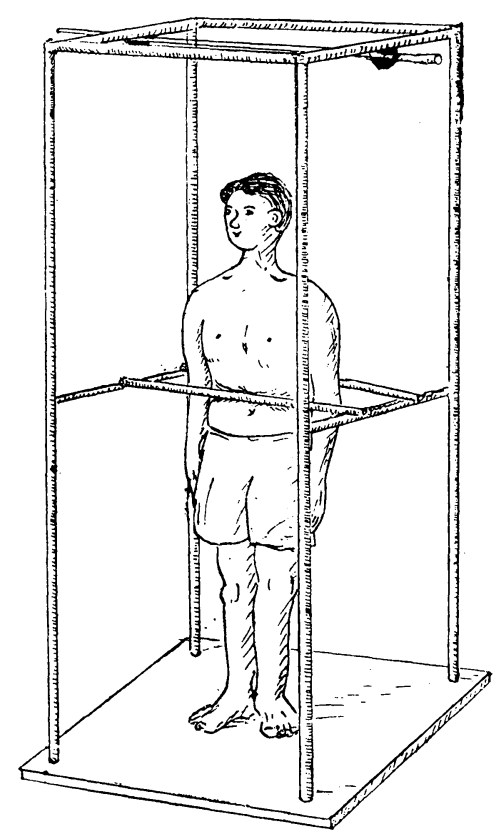

第; 4 圆

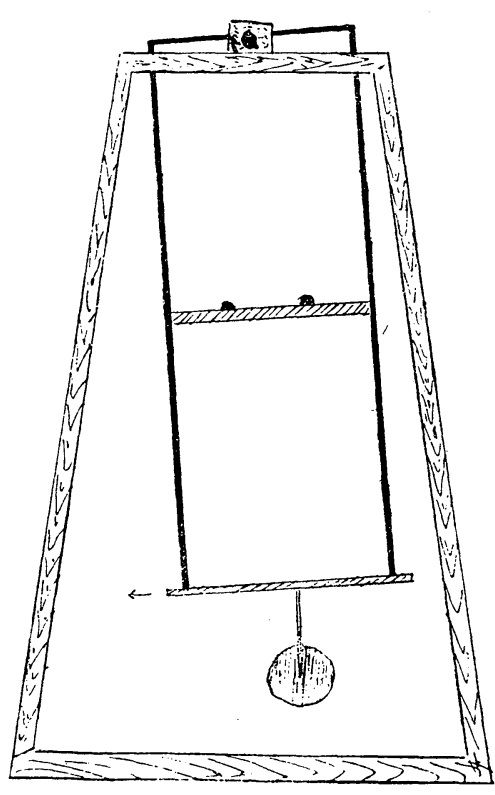

第５㘣 
右邊は何れも測定可能な量及び常數であるから（4）を用いて $O G=h$ を計算しらる。 以上は重心高の求め方を述べをものであるが、との過程に於て前後左右方向の重心位㯰、 いわば重心の深さが靜力學的に求められる。第 1 圖の剛體（ての場合ぶらんて）に一つの剛 體（人）が附加された時に、第 3 圖の如く最初の剛體が $\alpha$ だけ回轉して平衡の位置に達し をとすれば、第 2 の㴊體の重心と $\mathrm{O}$ を過ぎる鉛直線との距離 $x$ は

$x \mathrm{M}_{2}=h \mathrm{M} \sin \alpha$

として求められる。

實驗 I：一厚さ $3 \mathrm{~cm}$ の長方形の板の 4 箇所に穴を穿つて、とっに鐵製パイブを通して 支柱とし、その上部を鐵枠で固定して、ぶらんとの骨組が出來あがる。との上部の枠にボー ル・ベアリングを介して水本を鐵棒を連結し、鐵棒の兩端を固定した蟹て取りつける。との 際、人の體重に比して、ぶらんとの動く部分が輕い程、銳敏な重心測定器が出來る譯である が、堅牢さも犠牲にできない。こらして出來をぶらんてに被檢者を乘せて實驗行取りかかる。

被檢者は、ぶらんての動きに應じて本衡の位置を取ろらとするから、重心高を求めようと する姿勢で人體を固定してしまわなくてはならない。そのために支杜に取り附けた固定用具 で腹部及び頭部を締めつけ、ぶらんての多少の摇れでは動かないよ5にする。先に BASLER の方法を述べをが、ぶらんてと對して一定の力を加えて生ボつレの角から人體重心高を推 定するのは非常に危險であつて、重心高の變化よりも、重心の、換言すれば身體の前後の摇 れの方が遥かに强くフレに影響するととは明らかであろら。私の方法によれば、フレの角は 專ら重心の前後の水平斷面上の位置決定に用いられるのであつて、身體の摇れによる重心高 への影響は振子を多數回振動させるととによつて、遂次的に減少させよらといらのである。

先ホ被檢者をぶらんての振動する方向に面せしめて體を固定裝置によつて固定し、この時、 踏板側方中央に取りつけた指針が、踏板と平行に㯰かれた目盛をさす點を読む。式 (5)によ つて前後方向の重心の深さが得られる。郎ち

$$
x=\frac{\mathrm{M}}{\mathrm{M}_{2}} h \sin \alpha=\frac{\mathrm{M}}{\mathrm{M}_{2}} \cdot \frac{h}{l} \cdot y
$$

てっに M, $\mathrm{M}_{2}$ はぶらんて及び人の質量、 $h$ は豫め求めておいたぶらんての重心と回轉軸之 の距離であり、lは回轉軸之指針の指す目盛との距離で、軸と指針の距離を以て代用して差 し支えなん。目盛の山央、郎ちぶらんてが無荷重の場合に指針のさす位羁を $\mathrm{O}$ とし、 $\mathrm{cm}$ を單位として目盛が正負に刻まれているから、上によつてフレ $y$ を讀んで、重心が軸を含む 鉊直面の前或は後方に、ぼれだけ離れているかを知るととができる。

次に、ぶらんてを輕く抑して振動を開始する。乙の時、空氣抵抗も摩摖も影響しているか ら、振動注長い間續くにしても、結局次第に振巾が減少して遂に止んでしまら。特て着衣し た被檢者が用いられる時は、空氯抵抗が大きく、從つて週期にも相賞に響くのではないかと 考えられる。前記の式 (1) は抵抗、摩擦を無視したもので實際には速度に比例した空氣抵抗 $2 \varepsilon \frac{d x}{d t}$, 速度之常に逆符號を有する摩擦 $\mathrm{F}$ を考虑に入れて

$$
\frac{d^{2} x}{d t^{2}}+2 \varepsilon \frac{d x}{d t}+n^{2} x \pm \mathrm{F}=\mathrm{O} .
$$

としなくてはならない。振巾はてれを解いた

$$
x=k e^{-\varepsilon t} \cos \left(\sqrt{n^{2}-\varepsilon^{2}} t+\alpha\right) \mp \mathrm{F}
$$




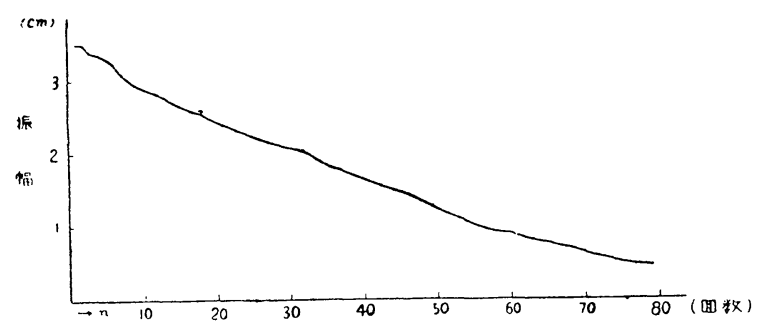

第 6 圖 最大振巾の時間的變化
であるから、理論式 (1) から得 られた振動數 $n=\frac{2 \pi}{\mathrm{T}}$ よりも、 振動數が減じて表われる。郎ち 見掛けの週期 $T^{\prime}$ が得られたな らば、空氣抵抗のない場合の週 期はこれに $\sqrt{n^{2}-\varepsilon^{2}} / n$ を乘じた ものとなる。との關係を調べる には振巾の變化を圖示してみる

のが便利であつて、抵抗、摩擦の索い場合汇不變である最大层巾は、速度に比例する抵抗の みが見られる場合には、第 6 圖から知られるように指數的に減塆し、摩擦のみが働く場合に は直線的減少する。乙の實驗では第 6 圖に見られる如く、抵抗、摩擦が共表れる。そと で適當な處理を行つた結果、空氣抵抗てよる影響を分離して $\sqrt{n^{2}-\varepsilon^{2}} / n$ を $\left(1-2 \times 10^{-6}\right)$ と見積るととができた。我々の實驗では、後述のように實驗誤差が $10^{-4}$ の桁よりも大きい ことを考えれば、空氣抵抗による補正は行わなくてもよいてとになる。

かくして、何度か振動する纪要する時間を回數で除してえを週期 Tををの劣〉用いるこ とができる。

週期 T の測定が終つた後、被檢者の姿勢を崩さが、素早くぶらんこの下方に鏵を取り つける。そこでまた振動を開始し、錘を荷重した際の週期 $\mathrm{T}^{\prime}$ を測定すれば、T, $\mathrm{T}^{\prime} を(4)$ に代入するととによつて人とぶらんととの綜合された重心と、回轉軸との距離を矨るととが できるわけである。

こっに注意すべきととは、かような實驗では、求めようとする值を算出するのに、椱雜な 演算を行わなくてはならない。郎ち多數の測定値をもとにして、一つの數值を計算するので あるから、それらの測定值の誤差が、種々の程度で求める結果涪影響するととになる。そと で豫め、個々の測定誤差と結果に於て表好礼る誤差との關係を調べておく必要がある。一般 飞 $x_{1}, x_{2}, \cdots \cdots x_{n}$ を測定して $y$ をる數值を計算する場合に、 $y$ の誤差㳄のよ5に計算さ れる。 $y=f\left(x_{1}, x_{2}, \cdots, x_{n}\right)$ で $y$ の值が定められるとし、 $x_{1}, x_{2}, \cdots x_{n}$ の誤差がそれぞれ $\delta x_{1}, \delta x_{2}$, $\cdots, \delta x_{n}$ であれば、 $y$ 亿生ずる誤差は

$$
d y=\Sigma \frac{\partial}{\partial x_{i}} f\left(x_{1}, x_{2}, \cdots, x_{n}\right) \delta x_{i} \text {. }
$$

この式を用いて (4)のんに生ずる誤差を計算してれを相對誤差で表現すれば

$$
\begin{aligned}
\frac{d h}{h} & =-\frac{\delta \mathrm{M}}{\mathrm{M}}+\frac{\delta \mathrm{M}_{1}}{\mathrm{M}_{1}}+\frac{2 a \mathrm{~A}-\mathrm{T}^{\prime 2}}{\mathrm{~A}\left(a+\frac{\mathrm{I}}{a \mathrm{M}_{1}^{-}}\right)-\mathrm{T}^{\prime 2}} \cdot \frac{\delta a}{a} \\
& +\frac{2}{\left(-\frac{\mathrm{T}^{\prime}}{\mathrm{T}}\right)^{2}-1} \frac{\delta \mathrm{T}}{\mathrm{T}}-\frac{2}{1-\left(\frac{\mathrm{T}}{\mathrm{T}^{\prime}}\right)^{2}} \frac{\mathrm{A}\left(a^{2}+\mathrm{I}_{1} / \mathrm{M}_{1}\right)-a \mathrm{~T}}{\mathrm{~A}\left(a^{2}+\mathrm{I}_{1} / \mathrm{M}_{1}\right)-a \mathrm{~T}^{\prime 2}} \cdot \frac{\delta \mathrm{T}^{\prime}}{\mathrm{T}^{\prime}}(7)
\end{aligned}
$$

をらる。この式から判るように錘 $M_{1}$ 、人體とぶらんての質量 $M$ は、それぞれの持つのと 同じ割合の誤差を結果するととになる。これに反し、錘と回轉軸との距離は $\frac{\delta a}{a}$ 係數丈摭 大されて影響を與えるので、M 等に比して相當精密に測定する必要がある。次の問題は週 
期の測定に伴5誤差であるが、無荷重の場合の週期 Tははぼ 30 回の振動の平均值を取る から、とれに要する 70 秒て對するストップ・ウォッチの精度 0.2 秒をもとにして、 $\frac{\delta T}{T}$ ほ $0.3 \%$ と考えるととができる。然るに $T^{\prime}=2.70 \mathrm{sec} . \mathrm{T}=2.37 \mathrm{sec}$ を、 $\frac{\delta \mathrm{T}}{\mathrm{T}}$ の係數に代入 すると 6.5 上りも大きくなつて、週期 $\mathrm{T}$ の測定誤差が求める $h$ に與える影響は $2 \%$ 亿達する ことになる。hは $1 \mathrm{~m}$ 位で两るから $2 \%$ は約 $2 \mathrm{~cm}$ に相當し，かなり大きな誤琹といわなく てはならない。然もてれに、荷重した場合の T片る誤差を加えれば、んに生する誤差は

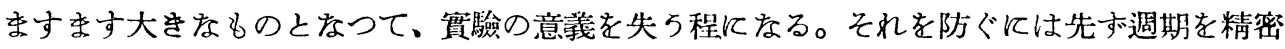
に測定するとと、Tと T' の差を大きくするととがあげられる。やがて述べるように第 2 の 改良法も後に用いてみたが、時間の都合で週期の精密測定を最初に試みた。そのため，電氣 的測定法を用い踏板の側面で、靜止時に回轉軸の鉛直下方に位㯰する所にコンタクトをつけ、 更に燐青銅のバネの上に小鋼鐵球をつけたものを他の固定されたコンタクトとして、ぶらん てが搖れて第 1 のコンタクトが回轉軸を含む鉛直面を切るときに回路が閉じるよらにしてあ る。そしててれをオッシログラフを用いて撮映するのであるが、時間の標集としては 100 cycle の音叉を用い、これとぶらんての 4 往復に要する時間とを比較して週期を決定するて とができる。ての方法によつて週期を $0.1 \%$ の誤差範圍におさめるてとができたので、結局 T, T'がんに於て $2 \%$ の誤差しか生じない所まで達した。

かくして得たんは、いわばぶらんとと人體との綜合重心であるから、人の重心高は床面上 から測つて

$$
s=l-h+\frac{m_{0}}{m}\left(s_{0}-h\right)
$$

となる。と〉に $l, s_{0}$ はぶらんての回轉軸から測つた踏板、ぶらんての重心迄の距離、 $m_{0}$ は ぶらんての重さ、 $m$ は體重である。

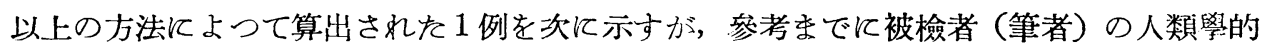
計測值を併記しておく。

體重: $64.2 \mathrm{~kg}$ 身長: $166.6 \mathrm{~cm}$ 胸骨上綠高: $136.7 \mathrm{~cm}$

恥骨縫合上緗高: $83.0 \mathrm{~cm}$ 右腸骨前上棘高: $91.3 \mathrm{~cm}$ 臍高: $95.2 \mathrm{~cm}$

重心高は 1 人の被檢者について種々の姿勢で求めてみた。

正常位 (BRAUS K依る) $99.8 \mathrm{~cm}( \pm 2 \mathrm{~cm})$

因みに週期は $\mathrm{T}^{\prime}=2.705 \mathrm{sec} . \mathrm{T}=2.374 \mathrm{sec} .( \pm 0.002 \mathrm{sec})$

である。

開を足（足を最短距離で測つて $50 \mathrm{~cm}$ 開いた對象的な姿勢。乙の時の身長 $161.9 \mathrm{~cm}$ ) $101.8 \mathrm{~cm}$

爪先立ち（兩足を $10 \mathrm{~cm}$ 程開いてできる丈背を伸す。身長 $174.9 \mathrm{~cm}$ ) $103.4 \mathrm{~cm}$

胡坐（普通に㐫ぐらをかく。頭頂の高さ $86.5 \mathrm{~cm}$ ) $33.2 \mathrm{~cm}$

正坐（足の第1趾を重ねて坐る。頭頂の高さ $101.2 \mathrm{~cm}$ ) $42.7 \mathrm{~cm}$

四つ匍い（爪先と手掌で體重を支えて腰を低くする） $30.9 \mathrm{~cm}$

遊び足（片足で體重の大部分を支え、他方の足は樂に伸して地に觸れる） $91.7 \mathrm{~cm}$

との際、多くの姿勢は對象的であるから、前頭面に於ける重心の位置は求めすれ、矢狀面 に於けるそれだけを決定した。 
實驗 II：一一筫驗 I の方法は、オッシログラフルよる撮映迄行つて、各計測值を精密に 求めたにも拊ら尗、結果に於て $2 \%$ の誤差を生じている。てれは（7）の式から判明するよう に、荷重、無荷重の場合の週期が接近しているために、最も測定困難な週期に生ずる誤差が 擴大されて影響するためである。そてで Tに比して、荷重した場合の $T^{\prime}$ を非常に大きく すれば、週期測定はそれ程嚴密に行万必要がなくなる。(4)を適當清き換えれば

$$
\frac{g}{4 \pi^{2}} \mathrm{~T}^{\prime 2}=\frac{\mathrm{I}+\mathrm{I}_{1}+a^{2} \mathrm{M}_{1}}{h \mathrm{M}+a \mathrm{M}_{1}}
$$

が得られて、 $\mathrm{T}^{\prime}$ を增すには $a, \mathrm{M}_{1}$ を增すと共に重要なととは、 $a$ の符號を代える、郎ち錘 の位置をぶらんての回轉軸の上方に持つてゆけばよいととになる。そのためには、錘が落下 する危險を防がねばならないし、さらに致命的なととには、荷重時沉於ける回轉能率が小さ くなる（錘をも考虑に入れてみれば、重心位置が軸に近ずく）ので、回轉軸に於ける摩擦が 極度に小さくなるょ5にしをければ、僅かの振動の間に、振巾は急速に減少して、多數回の 振動の平均を取るととによつて、週期の誤差を縮めようとする意圖に反する。電氣的測定と い5、費用、時間の要する方法から、ストップ・ウォッチによる測定といら方法に切りかえ るためには、實際、回轉軸に於ける摩擦を減じ、こっに優れを裝蛊を用いなくてはならない。 先ボボール・ベアリングに優秀なるのを用い，次いで、燐青銅テープによる吊りさげの方法 へと轉じたのはかっる理由によるのであつて、目下その實驗て移行している所である。

この方法により、步行時の重心の移動、成人の正常位に於ける重心高等を算出してみた。 前者は後に詳報するとして、後者の結果のみを記すれば次の如くである。日本人成人(主とし て大學生) 13名（身長：平均 $166.1, u=3.7$ ；右腸骨前上棘高：平均 $889, u=3.4$ ）の重心 高は、平均 $91 . \mathrm{cm}, u=4.3 \mathrm{~cm}$ であつた。但し實驗誤差は $1.5 \mathrm{~cm}$ であるので、ての數字を 更に詳しく分析するととは差控える。また比脚長（右腸骨前上棘高と身長との比を 100 倍 して代用した）と比重心高は相當な相關を示した $\left(r=0.88^{* *}\right)$ 。

後

記

以上は、人體力學の一端として、また人類學的計测の一分野として研究した重心高につい ての予俑的報紫である。主腿は任意の姿勢に於ける重心の位置を計算によつて捉え、かかる 研究に必然的江附隨する、實驗誤差を量的沉把握し、かつてれを逐次的に減少せしめるてと に置いたが、未だに十分な結果に到達していない。先顥驗方法の簡便化という點で、改良 の余地があり、更に他の研究者の結果と比較するためには、前述のREYMOND の方法を併用 するととも必要と考えている。人體といら、力學的には極めて動きやすい剛體では、重心を 正確江測定するととは相當に困難であるが、從來、困難であるというために、一方では全く の想像から重心位置を云々し、他方では、發展の余地のある研究が行われなかつたととの多 いのは殘念である。私は人體重心硎究史を檢討するととから始めて、上の困難を解決するた め潠ばるべき方法を求め、漸次的な改良によつて目的を果しらるものと考えている。

重心問題は私の卒業論文として選んだものであるが、終始䩿撻を頂いた人類學呚室須田助 㸚授、指導を惜しまれなかつた生理學敉室時實講師、人類學敉室の近藤、小片氏を始め、協 力を賜つ光方は非常に多い。といに感謝の意を表する次第で亦る。 


\section{A New Method for Measuring the Centre of Gravity in Man KAZUO TERADA}

Man is always under the influence of gravitation, and therefore, his structure and function are related to it. The determination of the centre of gravity is one of the most important problem in the study of man from the mechanical point of view. Hitherto, several methods have been used to determine the centre of gravity statically, such as Bonelli's (1677, a board counterpoised at the centre), REYmond's (1900, one lever and two fulcrums one of which is laid on the scale), etc. But, the fact that the centre of gravity is not a fixed point in the body but is constantly moving has been disregarded in the methods employed thus far. The centre of gravity has always been measured in the overlaying posture and we must seeh another way if we wish to know the centre of gravity at any given posture.

From about thirty years ago, A. BASLER has been studying its characteristics. He asserts that it is affected even by the pulse and it is necessary, therefore, to use a swing; the subject being made to stand in a given posture with a constant force applied against the swing, as a result of which the angle of deflection will be directly due to the height of the centre of gravity and the weight of the subject. His method, I think, is superior to the old ones, but has some faults, for example, if the subject changes his posture even slightly, the influence over the angle of deflection is considerable, and is more than the change of the height of gravity centre that must be measured.

Our method is free of this fault. We use the swing method, not statically, but dynamically : if the physical pendulum is made to oscillate, its period $(T)$ is exclusively due to the distance from the axis to the centre of gravity and the moment of inertia of the rigid body (1)-(2). Man's moment of inertia is, however, difficult to determine as well as the centre of gravity, and so some rigid body, of which both of these are known, is fixed to the pendulum. Again measure the period ( $T^{\prime}$ ), and you will find the distance to be obtained by eliminating the moment of inertia (3) -(4). The resistance of the air in proportion to the velocity and the friction of the bearings, which are attached to decrease the friction which operates to counter the direction of the velocity are both measured and found not to give rise to any need for correction of the results ((6), Fig. 6).

Such a complex computation as this causes necessarily considerable error in the result which is derived from each measurement. Formula (7) shows the relation of error and it is notable that the success of this experiment should depend on the measures of the T, T', and that accuracy should increase in proportion as $T^{\prime}$ is much more than $\mathrm{T}$.

On the principle above explained, we measured the centre of gravity in several postures of one subject, and those in normal standings of 13 subjects. Though the sample size is too small to justify definite conclusions, the correlation between the relative value of leg length and that of height of the centre of gravity was relatively high, which is contrary to ScheID's statements. This will be a matter of future research. 